\title{
Gender Differences in Selection of Investment Avenues in Solan Town of Himachal Pradesh
}

\author{
Neha Kashyap*, Arshia Bansal, Piyush Mehta and Raina Krishan Kumar
}

Dept. of Business Management, UHF, Nauni, Solan, Himachal Pradesh (173 230), India

\section{Corresponding Author}

Neha Kashyap

e-mail:nhkshp94@gmail.com

\author{
Article History \\ Article ID: AR1931 \\ Received in $22^{\text {nd }}$ November, 2018 \\ Received in revised form 09 ${ }^{\text {th }}$ January, 2019 \\ Accepted in final form $10^{\text {th }}$ January, 2019
}

\begin{abstract}
The study was conducted at Solan town of Himachal Pradesh. It has highlighted the key areas of gender differences in the selection of investment avenues in a very substantive manner. The study was undertaken with the objective of knowing the various investment avenues available to household investors and the factors influencing investment decision making and also the significant differences in factor influencing decision making with respect to gender. While studying the awareness level of the investors about the various investment avenues available, it was observed that males were largely inclined for investment options involving high risk, whereas females were more attracted towards the traditional investment avenues like gold and silver. Study revealed that the female gender are risk averse and invest small amount of their income in low risk investment avenues whereas male gender are risk seekers and invest larger part of their income in diversified investment avenues involving high risk. The comparative analysis found that the male respondents were more interested towards real-estate and the female respondents were active towards bank fixed deposits. Male investors prefer growth and income component whereas female investors were inclined for long-term growth component and safety aspect of investment. Most of the males and females respondents who have invested are from the mid age the investment companies should invent new investment schemes for targeting the other age group people. The investment companies should make new schemes which are less risky so that the mid income group people could also invest.
\end{abstract}

Keywords: Investment, investors, gender, risk, behaviour, investment avenues

\section{Introduction}

An investment is a commitment of funds made in the expectation of some positive rate of returns. If the investment is properly undertaken, the returns will commensurate with the risk the investor assumes (Fischer and Jordon, 1995). The process of investing helps to create financial markets where companies can raise capital. This too, contributes to greater economic growth and prosperity (Parimalkanthi and Kumar, 2015). An investors who makes an investment into one or more categories of assets-equity, debt securities, real estate, currency, commodity, derivatives such as put and call options, etc. with the objective of making a profit (Murithi et al., 2012).An understanding of the core concepts and a thorough analysis of the options can help an investor create a portfolio that maximizes returns while minimizing risk exposure (Mohanty, 2011). The various investment avenues available in the market are equity, preference, debentures, precious metal, gold, silver, real state, life insurance, public provident fund, mutual fund, fixed deposits, post office savings etc. (Raheja and Lamba, 2013). The average household expenditure of working women households was about $15 \%$ higher than non-working women households. Given, the much higher presence of women in both professional and personal investing, it is very important to understand the role of gender in investment decision making process (Gaur et al., 2011). The investors prefer to invest in particular Investment Avenue according to their need, risk bearing capacity and expected return. When the investors want high return they have to choose the investment avenue that is risky. (Jawaheer and Manual, 2016). For successful investors this overconfidence can be reinforced through self-attribution bias, i.e. belief that their trading success should be attributed mostly to their own abilities (Odean, 1998). The investors should be aware of the various hedging and speculation strategies, which can be used for reducing their risk. And awareness about the various uses of derivatives can help investors to reduce risk and increase profits (Ravichandran, 2008). It was discovered that there is a relationship between dependent variable i.e. risk tolerance level and independent variable such as age, gender of an individual investors (Sultana, 2010). People give more preference to saving and safety but that the same time they want higher interest at low risk in shorter span. Women are attracted towards investing gold than any other investment avenue (Brahmabhatt et al., 2012). The various factors 
influencing the investment behaviour of individual investors in Geojit BNP Paribas Financial Service Ltd, Coimbatore 'found that during the study majority of the respondents are influenced by the accounting information of the companies and advocate recommendations is the least influencing group (Ganesh and Santhi, 2012). Investments choice gets affected by the demography variables could help the financial advisors in building a successful relationship with their clients (Sireesha and Laxmi, 2013). In traditional investment options, women give more weight to gold and silver only. But, every investor should understand the relevance of portfolio real role of money in one's life (Kaur, 2015). Instead of making wrong decisions concerning investment, it is advisable that the investors should take help from the financial planners (Parimalakanthi and Kumar, 2015).

\section{Materials and Methods}

The descriptive research design was adopted for the concerned research study. The study was conducted in Solan town of Himachal Pradesh. The data was collected from household investors of Solan town.The respondents were selected by convenience sampling depending on availability of respondents. A total of 60 respondents consisting of 30 male and 30 female of different regions of Solan town who were involved in investment decisions were taken as sample size for this study.Primary data was collected through closed ended structured questionnaire. The questionnaire was designed to seek information on the demographic variables such as age, gender, education, income, etc. and general views and statements based on Likert scale to evaluate the awareness level and selection of different investment avenues by the investors.Secondary data was taken from journals, magazines, research articles, newspaper, and books.Simple mathematical and statistical tools, including Arithmetic mean, standard deviation, percentage and Total Weightage Score (TWS) methodwere used for satisfying the objectives with a view of keeping the analysis simple and easy to understand. The concerned research paper was initiated with the key objectives, to study the various investment avenues available to household investors, to find out the factors that influence investment decision and to find out the significant differences in factors influencing decision making with respect to gender.

\section{Results and Discussion}

\subsection{Age status of the respondents}

In reference to understand the age status of respondents, it was perceived that maximum $30 \%$ respondents consisted of age group comprised of 18-30 years among both the male and female category, whereas respondents were very least in age group of $41-50$ years among female category i.e. $10 \%$ and among male respondents category the least respondents i.e. $10 \%$ were found in the age group 61 years and above (Table 1 ).

\subsection{Gender Status of the respondents}

The ratio of males and females was being equal as we were

\begin{tabular}{lcc}
\hline \multicolumn{3}{l}{ Table 1: Age status of respondents } \\
\hline Age & $\begin{array}{c}\text { No. of respondent } \\
\text { female (\% age) }\end{array}$ & $\begin{array}{c}\text { No. of respondent } \\
\text { male (\% age) }\end{array}$ \\
\hline $18-30$ & $9(30)$ & $9(30)$ \\
$31-40$ & $4(13.33)$ & $8(26.67)$ \\
$41-50$ & $3(10)$ & $5(16.67)$ \\
$51-60$ & $8(26.67)$ & $5(16.66)$ \\
61 above & $6(20)$ & $3(10)$ \\
Total & $30(100)$ & $30(100)$ \\
\hline
\end{tabular}

Source: Primary probe, 2017; Percentage in brackets

checking the gender differences in selection of investment avenues, so the male female ratio has been kept equal for the convenience in this study (Table 2).

\begin{tabular}{lc}
\hline \multicolumn{2}{l}{ Table 2: Gender status of the respondents } \\
\hline Gender & No. of respondents (\%) \\
\hline Male & $30(50)$ \\
Female & $30(50)$ \\
Total & $60(100)$ \\
\hline
\end{tabular}

Source: Primary probe, 2017; Percentage in brackets

\subsection{Marital status of the respondents}

As per the marital status of the respondents in the research study is concerned, it was observed that maximum respondents were married in both the gender i.e. $66.67 \%$ amongfemales and $63.33 \%$ among males respondents category. The least unmarried respondents observed among females category were $33.33 \%$, whereas $36.67 \%$ were unmarried among the male category. It was categorically noted during the study that more investments weremadelargely by the married respondents among both the gender category revealing a fact that marital status may be considered as one of the stimulating factor for investments among the respondents largely (Table 3).

Table 3: Marital status of the respondents

\begin{tabular}{lcc}
\hline $\begin{array}{l}\text { Marital } \\
\text { status }\end{array}$ & $\begin{array}{c}\text { No. of respondent } \\
\text { female }(\% \text { age) }\end{array}$ & $\begin{array}{c}\text { No. of respondent } \\
\text { male (\% age) }\end{array}$ \\
\hline Married & $20(66.67)$ & $19(63.33)$ \\
Unmarried & $10(33.33)$ & $11(36.67)$ \\
Total & $30(100)$ & $30(100)$ \\
\hline
\end{tabular}

Source: Primary probe, 2017; Percentage in brackets

\subsection{Education status of the respondents}

The education status of the respondentswas observed that majority of the respondents were graduate amongboth the gender categories. It was $56.67 \%$ amongfemales and $43.33 \%$ among male respondents categories, which was observed to be maximum among both the gender categories. There were 
post-graduates also $26.67 \%$ as highest among males and $13.33 \%$ in females. Then there were diploma holders $23.33 \%$ in males and $10 \%$ in females. $10+2$ were highest among females $16.67 \%$ and $3.33 \%$ among males. Other courses done by both the gender were of ratio $3.33 \%$ and $3.34 \%$. As respondents were indulged in investment process, so there are more number of graduates and post-graduates (Table 4).

\begin{tabular}{lcc}
\hline \multicolumn{3}{l}{ Table 4: Education status of the respondents } \\
\hline $\begin{array}{l}\text { Educational } \\
\text { background }\end{array}$ & $\begin{array}{c}\text { No. of respondent } \\
\text { female (\%) }\end{array}$ & $\begin{array}{c}\text { No. of respondent } \\
\text { male (\%) }\end{array}$ \\
\hline Matric & $0(0)$ & $0(0)$ \\
$10+2$ & $5(16.67)$ & $1(3.33)$ \\
Diploma & $3(10)$ & $7(23.33)$ \\
Graduation & $17(56.67)$ & $13(43.33)$ \\
Post-graduation & $4(13.33)$ & $8(26.67)$ \\
Others & $1(3.33)$ & $1(3.34)$ \\
Total & $30(100)$ & $30(100)$ \\
\hline
\end{tabular}

Source: Primary probe, 2017; Percentage in brackets

\subsection{Occupation/profession status of respondents}

While analysing the occupation/profession of the respondents, majority of respondents in both the gender were salaried, wheremales were $60 \%$ and females were $43.33 \%$. After that the maximum percentage was seen in other sources i.e. $36.67 \%$ in females. Business was done mostly by males $23.33 \%$ and females were less involved into business $13.33 \%$. Professionals were also very less $6.67 \%$ females which was greater than the males i.e. 3.33\%. It was noted that salaried people were more active in making investment according to this study (Table 5).

\begin{tabular}{lcc}
\hline \multicolumn{3}{l}{ Table 5: Occupation/ profession status of respondents } \\
\hline $\begin{array}{l}\text { Occupation / } \\
\text { profession }\end{array}$ & $\begin{array}{c}\text { No. of respondent } \\
\text { female (\%) }\end{array}$ & $\begin{array}{c}\text { No. of respondent } \\
\text { male (\%) }\end{array}$ \\
\hline Salaried & $13(43.33)$ & $18(60)$ \\
Professional & $2(6.67)$ & $1(3.33)$ \\
Business & $4(13.33)$ & $7(23.33)$ \\
Other & $11(36.67)$ & $4(13.33)$ \\
Total & $30(100)$ & $30(100)$ \\
\hline
\end{tabular}

Source: Primary probe, 2017; Percentage in brackets

\subsection{Monthly income status of respondents}

The monthly income of respondents was observed that among the total respondents, $56.67 \%$ of males fall in the category of ₹ 20,000- ₹ 40,000 monthly income which was highest among the male respondents and $53.33 \%$ of females lie in the category of below $₹ 20,000$ which was highest among the female respondents. And the least number of respondents were seen in the category of ₹ 40,000 and above in both the gender i.e. $16.66 \%$ males and $13.34 \%$ females. Fluctuations has been seen among the gender classes related to their earning capacity (Table 6).

\begin{tabular}{|c|c|c|}
\hline $\begin{array}{l}\text { Monthly } \\
\text { income }\end{array}$ & $\begin{array}{l}\text { No. of respondent } \\
\text { female (\%) }\end{array}$ & $\begin{array}{c}\text { No. of respondent } \\
\text { male }(\%)\end{array}$ \\
\hline $\begin{array}{l}\text { Below ₹ } \\
20,000\end{array}$ & $16(53.33)$ & $8(26.67)$ \\
\hline $\begin{array}{l}₹ 20,000-₹ \\
40,000\end{array}$ & $10(33.33)$ & 17 (56.67) \\
\hline $\begin{array}{l}₹ 40,000 \text { and } \\
\text { above }\end{array}$ & $4(13.34)$ & $5(16.66)$ \\
\hline Total & 30 (100) & 30 (100) \\
\hline
\end{tabular}

Source: Primary probe, 2017; Percentage in brackets

\subsection{Awareness level regarding the investment avenues}

While checking the awareness level of gender towards the investment avenues, it was observed that investment avenues has been categorized into 5 segments according to the risk involved along with the traditional and emerging investment avenues. In the first segment i.e. safe/low risk investment avenues observed that the male respondents were more likely to invest in the public provident fund $30 \%$ and were less inclined towards government securities 3.33\%. On the other side, female respondents invested largely towards the bank saving account and post office savings i.e. both $26.67 \%$ and were least interested towards national saving certificate and government securities $6.66 \%$. The data indicates that female respondents invested the smaller part of their income monthly or yearly in the banks and post offices whereas males were interested towards saving in PPF to get lump sum amount in future. In the moderate risk investment avenues segment, it was seen that males were more interested towards investing in mutual funds $46.67 \%$ whereas females preferred to invest in the life insurance schemes $60 \%$. It implied that females were investing for safe future of their families and also in a safer investment avenues, whereas males were investing with the motive of multiplying the invested income in a short period of time for liquidity and also for growth and income. High risk investment avenues as the name implies involves high degree of risk but also high profits even. The maximum number of male respondents i.e. $76.67 \%$ were interested in investing in the commodity market which involves high degree of risk and on the other side, $60 \%$ of females were interested in investing in the equity share market. From data it was observed that males were comfortable in taking more risk as compared to females, large number of male respondents agreed to invest in the high risk investment avenues as it yielded high profits. Female's respondents were also seen actively investing in the equity share market this can be due to the awareness among the female gender regarding different investment avenues available and also their high incomes. Traditional investment avenues which had been still very popular and powerful among the other investment options available in 
the market like real estate, gold \& silver were most preferred by both the gender. It was observed that men were more attracted towards real estate $53.33 \%$ and females were attracted towards gold and silver $73.33 \%$. This had been due to the reason that females admired precious metals more as compared to men and males liked trading business since years.In the emerging investment avenues, it had been seen that males were more aware and active towards investing in the new investment avenues as compared to females. Large number of percentage of respondents was seen in male gender as compared to females. Males were more attracted towards hedge funds with $40 \%$ and $46.67 \%$ of females liked to invest their money in private equity investment. It was noted that females were investing to get long term profits from the investments, whereas the males were investing to get short term benefits as hedge funds had been considered to be highly liquid investment avenues (Table 7).

Table 7: Awareness level regarding the investment avenues

\begin{tabular}{|c|c|c|}
\hline Investment avenues & Male (\%) & Female (\%) \\
\hline \multicolumn{3}{|c|}{ Safe/low risk investment avenues } \\
\hline Saving account & $3(10)$ & $8(26.67)$ \\
\hline Bank fixed deposit & $8(26.67)$ & $7(23.33)$ \\
\hline Public provident funds & $9(30)$ & $3(10)$ \\
\hline National saving certificate & $4(13.33)$ & $2(6.67)$ \\
\hline Post office savings & $5(16.67)$ & $8(26.67)$ \\
\hline Govt. securities & $1(3.33)$ & $2(6.67)$ \\
\hline \multicolumn{3}{|c|}{ Moderate risk investment avenues } \\
\hline Mutual funds & $14(46.67)$ & $7(23.33)$ \\
\hline Life insurance & $10(33.33)$ & $18(60)$ \\
\hline Debentures & $6(20)$ & $5(16.67)$ \\
\hline \multicolumn{3}{|l|}{ High risk investment avenues } \\
\hline Equity share market & $3(10)$ & $18(60)$ \\
\hline Commodity market & $23(76.67)$ & $12(40)$ \\
\hline Forex market & $4(13.33)$ & $0(0)$ \\
\hline \multicolumn{3}{|c|}{ Traditional investment avenues } \\
\hline Real estate (property) & $16(53.33)$ & $1(3.33)$ \\
\hline Gold/silver & $2(6.67)$ & $22(73.33)$ \\
\hline Chit funds & $12(40)$ & $7(23.33)$ \\
\hline \multicolumn{3}{|c|}{ Emerging investment avenues } \\
\hline Virtual real estate & $10(33.33)$ & $9(30)$ \\
\hline Hedge funds & $12(40)$ & $7(23.33)$ \\
\hline Private equity investment & $8(26.67)$ & $14(46.67)$ \\
\hline
\end{tabular}

Source: Primary probe, 2017; Percentage in brackets

3.8. Comparative analysis of preferable tool of investment in accordance to gender variable

In reference to the comparative analysis of preferable tool of investment in accordance to gender variable, it was observed that male gender specifically inclined to choose real estate options largely followed by foreign exchange market and commodity market investment as well. Since male respondents were likely to park their investment for long term where returns had been largely more as compared to other options thereby real estate had been more preferable among them. However, female gender were observed to be inclined towards short-term investment options largely, the total weightage score method (TWS) was computed in understanding the same inclination, it resulted that female gender preferred to place their investment substantially at bank fixed or recurring deposits followed by commodity market investments and even government security investment as well. Bank deposits including fixed or recurring had been considered to be of low return values with low risk but for a long term.Thus, it was being preferred by the female gender. Males are risk seekers and looking for long time horizon investment avenues. Thus, schemes available in bank shall always be considered for the preference by the gender and could also be helpful for the bank to fetch the larger number of investors. Further statistical tool including mean and standard deviation were also computed on both the gender data information in order to understand the investor preference towards different investment options. Male respondents were observed with the maximum average of 8.1 towards first rank to all the given investment options. Standard deviation being 2.1 (least)as third rank might be due to unawareness towards investment options.But overall, the male respondents were positive and enthusiastic about knowing and getting maximum information of all the investment options available in the market. While analysing the female respondents' data, it was observed that female respondents were also quiet enthusiastic on all the investment options available being the highest mean of 8.9 towards rank one.Standard deviation (3.5) revealed that female respondents had commonly a good consensus to know and get aware about various options available in the market regarding investments (Table 8 ).

\subsection{Time horizon for investment}

While analysing the time horizon adopted by the investors for their investments, it was observed that the female respondents were more likely to invest on quarterly basis i.e. $30 \%$ which was higher amongst the other options like monthly $26.67 \%$, more than 1 year but less than 5 yr. $16.67 \%$. Male respondents were observed to invest more on intra-day basis i.e. $26.67 \%$ and also in the time period of more than 1 year but less than 5 years. i.e. also $26.67 \%$. It was noted that females were investing from their savings which were likely to happen after 4 month or sometimes even after 1year or 5 year. On the contrary, males were observed to invest regularly to get short-term benefits and also in long-term investment avenues to get high profits (Table 9).

\subsection{Proportion of monthly income invested}

It was observed that the proportion of income invested by the 


\begin{tabular}{|c|c|c|c|c|c|c|c|c|c|c|}
\hline \multirow[t]{3}{*}{ Investment avenues } & \multicolumn{3}{|c|}{ Male (weightage) } & \multirow[t]{3}{*}{ TWS* } & \multirow[t]{3}{*}{ Rank } & \multicolumn{3}{|c|}{ Female (weightage) } & \multirow{3}{*}{ TWS } & \multirow{3}{*}{ Ranl } \\
\hline & (3) & (2) & (1) & & & (3) & $(2)$ & (1) & & \\
\hline & I & ॥ & III & & & 1 & II & III & & \\
\hline Saving account & $3(9)$ & $2(4)$ & $1(1)$ & 14 & $x V$ & $12(36)$ & $10(20)$ & $8(8)$ & 64 & VI \\
\hline Bank fixed deposit & $4(12)$ & $3(6)$ & $2(2)$ & 20 & XIV & $16(48)$ & $13(26)$ & $1(1)$ & $75^{* *}$ & I \\
\hline Public provident funds & $7(21)$ & $5(10)$ & $4(4)$ & 35 & $\mathrm{IX}$ & $10(30)$ & $9(18)$ & $11(11)$ & 59 & VII \\
\hline National saving certificate & $6(18)$ & $3(6)$ & $1(1)$ & 25 & XII & $8(24)$ & $9(18)$ & $13(13)$ & 45 & $\mathrm{XI}$ \\
\hline Post office savings & $2(6)$ & $2(4)$ & $1(1)$ & 11 & $\mathrm{XVI}$ & $13(39)$ & $10(20)$ & $7(7)$ & 66 & IV \\
\hline Govt. securities & $5(15)$ & $3(6)$ & $5(5)$ & 26 & $X I$ & $15(45)$ & $8(16)$ & $6(6)$ & 67 & III \\
\hline Mutual funds & $10(30)$ & $7(14)$ & $5(5)$ & 49 & V & $5(15)$ & $4(8)$ & $3(3)$ & 26 & XIV \\
\hline Life insurance & $6(18)$ & $4(8)$ & $2(2)$ & 28 & $x$ & $9(27)$ & $11(22)$ & $9(9)$ & 58 & VIII \\
\hline Debentures & $9(27)$ & $8(16)$ & $7(7)$ & 50 & IV & $4(12)$ & $2(4)$ & $2(2)$ & 18 & $X V I$ \\
\hline Equity share market & $11(33)$ & $5(10)$ & $4(4)$ & 47 & $\mathrm{VI}$ & $5(15)$ & $6(12)$ & $3(3)$ & 30 & XIII \\
\hline Commodity market & $12(36)$ & $7(14)$ & $5(5)$ & 55 & III & $15(45)$ & $12(24)$ & $3(3)$ & 72 & II \\
\hline Forex market & $13(39)$ & $10(20)$ & $6(6)$ & 65 & II & $7(21)$ & $8(16)$ & $4(4)$ & 41 & XII \\
\hline Real estate (Property) & $15(45)$ & $12(24)$ & $3(3)$ & $72^{* *}$ & I & $2(6)$ & $2(4)$ & $2(2)$ & 12 & XVIII \\
\hline Gold/silver & $8(24)$ & $6(12)$ & $4(4)$ & 40 & VIII & $13(39)$ & $10(20)$ & $6(6)$ & 65 & v \\
\hline Chit funds & $7(21)$ & $7(14)$ & $6(6)$ & 41 & VII & $3(9)$ & $2(4)$ & $1(1)$ & 14 & $X V I I$ \\
\hline Virtual real estate & $12(36)$ & $1122)$ & $7(7)$ & 65 & II & $9(27)$ & $8(16)$ & $3(3)$ & 46 & $\mathrm{x}$ \\
\hline Hedge funds & $8(24)$ & $4(8)$ & $3(3)$ & 35 & IX & $5(15)$ & $4(8)$ & $2(2)$ & 25 & $X V$ \\
\hline Private equity investment & $7(21)$ & $1(2)$ & $1(1)$ & 24 & XIII & $10(30)$ & $9(18)$ & $8(8)$ & 56 & IX \\
\hline Mean & 8.1 & 5.6 & 3.7 & & Mean & 8.9 & 7.6 & 5.1 & & \\
\hline SD & 3.6 & 3.2 & 2.1 & & SD & 4.4 & 3.5 & 3.6 & & \\
\hline
\end{tabular}

Source: Primary probe, 2017 ; *Total weightage score; ** $(15 \times 3+12 \times 2+3 \times 1=72) ; * *(16 \times 3+13 \times 2+1 \times 1=75)$

different investors, $33.33 \%$ of female respondents invested $16-20 \%$ of their personal income in the investment avenues. $30 \%$ of males invested larger part of their income i.e. $21-25 \%$ as compared to females. It was observed that males liked to invest larger part of their income as respondents' percentage was more in larger proportion of income. Comparatively,

\begin{tabular}{lcc}
\hline \multicolumn{3}{l}{ Table 9: Time horizon for investment } \\
\hline $\begin{array}{l}\text { Time horizon for } \\
\text { Investment }\end{array}$ & $\begin{array}{c}\text { No. of respondent } \\
\text { female (\%) }\end{array}$ & $\begin{array}{c}\text { No. of respondent } \\
\text { male (\%) }\end{array}$ \\
\hline $\begin{array}{l}\text { Intra-day } \\
\text { Within a month }\end{array}$ & $\begin{array}{c}3(10) \\
8(26.67)\end{array}$ & $7(23.33)$ \\
Within a quarter & $9(30)$ & $3(10)$ \\
Within a year & $4(13.33)$ & $2(6.67)$ \\
$\begin{array}{l}\text { More than } 1 \text { year. } \\
\text { but less than } 5\end{array}$ & $5(16.67)$ & $8(26.67)$ \\
years & & \\
More than 5 years & $1(3.33)$ & $2(6.67)$ \\
Total & $30(100)$ & $30(100)$ \\
\hline
\end{tabular}

Source: Primary probe, 2017; Percentage in brackets female respondents were tend to invest smaller part of their income. This was due to the reason that males were tend to take more risk by investing their income in diversified investment avenues whereas female respondents were tend to invest their income in low risk (Table 10).

\begin{tabular}{lcc}
\hline \multicolumn{3}{l}{ Table 10: Proportion of monthly income investment } \\
$\begin{array}{l}\text { Proportion of } \\
\text { income invested }\end{array}$ & $\begin{array}{c}\text { No. of respondent } \\
\text { female (\%) }\end{array}$ & $\begin{array}{c}\text { No. of respondent } \\
\text { male (\%) }\end{array}$ \\
\hline $0-10 \%$ & $5(16.67)$ & $3(10)$ \\
$11-15 \%$ & $8(26.67)$ & $2(6.67$ \\
$16-20 \%$ & $10(33.33)$ & $3(10)$ \\
$21-25 \%$ & $3(10)$ & $9(30)$ \\
$26-30 \%$ & $2(6.67)$ & $8(26.67)$ \\
$31-40 \%$ & $2(6.67)$ & $5(16.67)$ \\
Total & $30(100)$ & $30(100)$ \\
\hline
\end{tabular}

Source: Primary probe, 2017; Percentage in brackets

\subsection{Amount of return expected}

It was observed that the amount of return expected by the 
investors from their investment made, maximum number of female respondents i.e. $23.33 \%$ expected $11-15 \%$ range of returns from their investments made by them. $26.67 \%$ of male respondents expected $31-40 \%$ range of returns from their investment. From the data, it was seen that the return expectation of male respondents was much higher than the female. This was due to the reason that the female respondents were tend to invest in the low risk investment avenues which hadfixed returns. Males were tend to invest in diversified investment avenues, so their expectation for return was also high (Table 11).

\begin{tabular}{lcc}
\hline \multicolumn{3}{l}{ Table 11: Amount of return expected } \\
\hline $\begin{array}{l}\text { Amount of re- } \\
\text { turn expected }\end{array}$ & $\begin{array}{c}\text { No. of respondents } \\
\text { female (\% age) }\end{array}$ & $\begin{array}{c}\text { No. of respondents } \\
\text { male (\% age) }\end{array}$ \\
\hline $5-10 \%$ & $3(10)$ & $1(3.33)$ \\
$11-15 \%$ & $7(23.33)$ & $2(6.67$ \\
$16-20 \%$ & $6(20)$ & $3(10)$ \\
$21-25 \%$ & $5(16.67)$ & $4(13.33)$ \\
$26-30 \%$ & $4(13.33)$ & $5(16.67)$ \\
$31-40 \%$ & $3(10)$ & $8(26.67)$ \\
More than 40\% & $2(6.67)$ & $7(23.33)$ \\
Total & $30(100)$ & $30(100)$ \\
\hline
\end{tabular}

Source: Primary probe, 2017; Percentage in brackets

\subsection{Frequency of availing investment information from different sources}

While analysing frequency of availing investment information from different sources, it was analysed with the help of total weightage score method (TWS) and further a ranking was done on gender basis. It resulted that male respondents were more inclined to avail information from television and workplace area and even newspaper and magazines. Female respondents preferred to avail information from friends and colleagues, as females were observed to be more socially inclined, thus they tend to get influenced from their friends and colleagues. Further male respondents were largely observed to get information from the different sources as availed through the mean of 9.9 in the same segment though the standard deviation was observed to be minimum i.e. 3.9. As male respondents were tend to use different sources to generate information using almost all the sources quiet equally the level of information was observed to be quite high among them. On the contrary, female respondents having mean highest 8.9 at the seldom segment and the standard deviation was observed to be minimum i.e. 5.3 in the segment of very often. Thus female respondents were tend to use the given option of sources quiet largely. Thus, resulted that their awareness level were observed to be quiet weak towards various investment options and knowledge of the market (Table 12).

3.13. Source of influencing investment decision in reference

\section{to gender variables}

There were different sources of influencing investment decisions of investors in making their investment, some of the sources were taken in this structured questionnaire and the response of both the gender was evaluated. The total weightage score method TWS was applied and resulted that the male respondents scored high i.e. $86 \%$ in the option of 'no one'. It implied that majority of the male respondents might not likely to depend upon anyone to take their investment decisions. Masculinity also was observed to be a reason among the male in taking their own decisions by themselves only. Further, it was seen that some of them involve their families in making investment decision and even friends and colleagues were also considered while taking decisions. Female respondents were influenced largely by the professional associations for making their investment decision. Further, they were found taking expert opinions and even they dependent on the agents for making their investment decision. It was also observed that the female respondents were more serious and practical in making such investment decisions as they were taking help from the qualified professional associations, experts and even the agents. There could be another reason that the females were more social towards the society, so they got easily influenced by these professional association, experts and agents etc. Statistical tool including mean and standard deviation were also computed. Male respondents were considering a moderate level of influence largely towards various sources of influencing investment decision. Female respondents considered to get influenced by various available sources of investment information to the level of some extent. However it was noted that female respondents were at the level of a great extent of influencing from the given source of investment information. Thus, male respondents were more self-centred in investment decision, whereas female investors depended largely on professionals, agents etc. for their decision making (Table 13).

\subsection{Investment objective}

While analysing the investment objectives of investors from the investments done by them in the different investment avenues, it was observed that the most preferred investment objective among the female respondents were interest rates i.e. $96.67 \%$ followed by safety i.e. $93.33 \%$ and long-term growth $90 \%$. Among male respondents the most preferred aspects was observed with the investment objective of growth and income i.e. 93.33\% followed by capital appreciation i.e. $90 \%$ and short-term growth i.e. $86.67 \%$ etc. The data indicated that women's make investments safely without taking risks and on the other side men make investment for capital appreciation which involve high risk (Table 14).

3.15. Level of satisfaction achieved in the following investment objective

While analysing the level of satisfaction achieved from the investment objective, total weightage score was computed 


\begin{tabular}{|c|c|c|c|c|c|c|c|}
\hline Sources & Never (0) & Seldom (1) & Sometimes (2) & Often (3) & Very often (4) & TWS $^{*}$ & Rank \\
\hline \multicolumn{8}{|l|}{ Male (Weightage) } \\
\hline Financial advisor & $1(0)$ & $8(8)$ & $8(16)$ & $7(21)$ & $7(28)$ & 73 & V \\
\hline Internet & $0(0)$ & $3(3)$ & $12(24)$ & $8(24)$ & $7(28)$ & 79 & IV \\
\hline Newspaper and magazine & $0(0)$ & $6(6)$ & $8(16)$ & $4(12)$ & $12(48)$ & 82 & III \\
\hline Workplace & $0(0)$ & $10(10)$ & $13(26)$ & $5(45)$ & $2(8)$ & 89 & II \\
\hline Friends and colleagues & $0(0)$ & $7(7)$ & $15(30)$ & $4(12)$ & $4(16)$ & 65 & VII \\
\hline TV & $0(0)$ & $2(2)$ & $3(6)$ & $15(45)$ & $10(40)$ & $93^{* *}$ & I \\
\hline Radio & $0(0)$ & $3(3)$ & $17(34)$ & $5(15)$ & $5(20)$ & 72 & VI \\
\hline Investment club & $0(0)$ & $20(20)$ & $3(6)$ & $5(15)$ & $2(8)$ & 49 & VIII \\
\hline Any other place & $0(0)$ & $30(30)$ & $0(0)$ & $0(0)$ & $0(0)$ & 30 & IX \\
\hline Mean & 0.1 & 9.9 & 8.8 & 5.9 & 5.4 & & \\
\hline SD & 0.3 & 9.3 & 5.9 & 4.1 & 3.9 & & \\
\hline \multicolumn{8}{|l|}{ Female (Weightage) } \\
\hline Financial Advisor & $0(0)$ & $3(3)$ & $7(14)$ & $10(30)$ & $10(40)$ & 87 & II \\
\hline Internet & $0(0)$ & $12(12)$ & $15(30)$ & $2(6)$ & $1(4)$ & 52 & VI \\
\hline Newspaper and magazine & $0(0)$ & $7(7)$ & $8(16)$ & $9(27)$ & $6(24)$ & 74 & V \\
\hline Workplace & $0(0)$ & $30(30)$ & $0(0)$ & $0(0)$ & $0(0)$ & 30 & VIII \\
\hline Friends and colleagues & $0(0)$ & $0(0)$ & $0(0)$ & $20(60)$ & $10(40)$ & $100^{* *}$ & I \\
\hline TV & $0(0)$ & $15(15)$ & $15(30)$ & $0(0)$ & $0(0)$ & 45 & VII \\
\hline Radio & $0(0)$ & $7(7)$ & $7(14)$ & $7(21)$ & $9(36)$ & 78 & IV \\
\hline Investment club & $0(0)$ & $6(6)$ & $6(12)$ & $9(27)$ & $9(36)$ & 81 & III \\
\hline Any other place & $0(0)$ & $0(0)$ & $5(10)$ & $10(30)$ & $15(60)$ & 100 & 1 \\
\hline Mean & 0.0 & 8.9 & 7.0 & 7.4 & 6.7 & & \\
\hline SD & 0.0 & 9.4 & 5.4 & 6.3 & 5.3 & & \\
\hline
\end{tabular}

Source: Primary probe, 2017 ; ${ }^{*}$ Total weightage score; $* *(0 \times 0+2 \times 1+3 \times 2+15 \times 3+10 \times 4=93) ; * *(0 \times 0+0 \times 1+0 \times 2+20 \times 3+10 \times 4=100)$

\begin{tabular}{|c|c|c|c|c|c|c|}
\hline Influenced by & $\begin{array}{l}\text { To a great extent } \\
\text { (4) }\end{array}$ & $\begin{array}{c}\text { To some extent } \\
\text { (3) }\end{array}$ & $\begin{array}{l}\text { To a moderate level } \\
\text { (2) }\end{array}$ & $\begin{array}{c}\text { To an insignificant } \\
\text { level (1) }\end{array}$ & TWS* & Rank \\
\hline \multicolumn{7}{|l|}{ Male (Weightage) } \\
\hline Family members & $7(28)$ & $8(24)$ & $8(16)$ & $7(7)$ & 75 & II \\
\hline Relatives & $7(28)$ & $3(9)$ & $12(24)$ & $8(8)$ & 69 & IV \\
\hline No. one & $12(48)$ & $6(18)$ & $8(16)$ & $4(4)$ & $86^{* *}$ & 1 \\
\hline $\begin{array}{l}\text { Professional } \\
\text { association }\end{array}$ & $2(8)$ & $10(30)$ & $13(26)$ & $5(5)$ & 69 & IV \\
\hline Friends and colleagues & $4(16)$ & $7(21)$ & $15(30)$ & $4(4)$ & 71 & III \\
\hline Agents & $10(40)$ & $2(6)$ & $3(6)$ & $15(15)$ & 67 & VI \\
\hline Expert opinion & $5(20)$ & $3(9)$ & $17(34)$ & $5(5)$ & 68 & V \\
\hline Mean & 6.7 & 5.6 & 10.9 & 6.9 & & \\
\hline SD & 3.5 & 3.0 & 4.8 & 3.9 & & \\
\hline
\end{tabular}




\begin{tabular}{|c|c|c|c|c|c|c|}
\hline Influenced by & $\begin{array}{l}\text { To a great extent } \\
\text { (4) }\end{array}$ & $\begin{array}{c}\text { To some extent } \\
\text { (3) }\end{array}$ & $\begin{array}{c}\text { To a moderate level } \\
\text { (2) }\end{array}$ & $\begin{array}{c}\text { To an insignificant } \\
\text { level (1) }\end{array}$ & TWS* & Rank \\
\hline \multicolumn{7}{|l|}{ Female (Weightage) } \\
\hline Family members & $10(40)$ & $3(9)$ & $7(14)$ & $10(10)$ & 73 & IV \\
\hline Relatives & $1(4)$ & $12(36)$ & $15(30)$ & $2(2)$ & 72 & V \\
\hline No One & $6(24)$ & $7(21)$ & $8(16)$ & $9(9)$ & 70 & VI \\
\hline Professional association & $0(0)$ & $30(90)$ & $0(0)$ & $0(0)$ & $90^{* *}$ & I \\
\hline $\begin{array}{l}\text { Friends and } \\
\text { colleagues }\end{array}$ & $10(40)$ & $0(0)$ & $\begin{array}{c}0 \\
(0)\end{array}$ & $20(20)$ & 60 & VII \\
\hline Agents & $0(0)$ & $15(45)$ & $15(30)$ & $0(0)$ & 75 & III \\
\hline Expert opinion & $9(36)$ & $7(21)$ & $7(14)$ & $7(7)$ & 78 & II \\
\hline Mean & 5.1 & 10.6 & 7.4 & 6.9 & & \\
\hline SD & 4.7 & 9.9 & 6.1 & 7.1 & & \\
\hline
\end{tabular}

Source: Primary probe, $2017 ;{ }^{*}$ Total Weightage Score; ${ }^{* *}(12 \times 4+6 \times 3+8 \times 2+4 \times 1=86) ; * *(0 \times 4+30 \times 3+0 \times 2+0 \times 1=90)$

\begin{tabular}{lcc}
\hline \multicolumn{3}{l}{ Table 14: Investment objective } \\
$\begin{array}{l}\text { Investment } \\
\text { objective }\end{array}$ & $\begin{array}{c}\text { No. of respondent } \\
\text { female (\% age) }\end{array}$ & $\begin{array}{c}\text { No. of respondent } \\
\text { male (\% age) }\end{array}$ \\
\hline Interest rates & $29(96.67)$ & $20(66.67)^{*}$ \\
Dividends & $15(50)$ & $25(83.33)$ \\
Capital appreciation & $19(63.33)$ & $27(90)$ \\
Safety & $28(93.33)$ & $15(50)$ \\
Liquidity & $14(46.67)$ & $19(63.33)$ \\
Tax Benefits & $20(66.67)$ & $23(76.67)$ \\
Long-term growth & $27(90)$ & $18(60)$ \\
Short-term growth & $13(43.33)$ & $26(86.67)$ \\
Growth and income & $22(73.33)$ & $28(93.33)$
\end{tabular}

Source: Primary probe, 2017; Percentage in brackets; N(Total no. of respondents) $=30 ; *=20 \times 100 / 30$

which showed that male investors were more inclined towards growth and income component closely followed by dividends based investment objective. Whereas, female investors were inclined for long-term growth component and safety aspect of investment objective. Thus, considering the given component of investment objective gender wise it may have been suggested that financial institution should consider these specific component while designing the investment schemes for the different categories of investors specifically in accordance to gender. Further data was analysed with the help of mean and standard deviation resulting that both male and female investor were highly satisfied with their existing investment objective. However, both the male and female investor had a consensus towards dissatisfaction that largely may be on account of lack of awareness and participation. Since investment objective were considered to be of high satisfaction oriented aspect among both the gender, it may have a high significance to the investors while planning and allocating their respective investment options (Table 15).
Table 15: Level of satisfaction achieved in the following investment objective

\begin{tabular}{|c|c|c|c|c|c|c|c|}
\hline Influenced by & 1 & 2 & 3 & 4 & 5 & TWS $^{*}$ & Rank \\
\hline \multicolumn{8}{|c|}{ Male (Weightage) } \\
\hline $\begin{array}{l}\text { Interest } \\
\text { Rates }\end{array}$ & $\begin{array}{l}10 \\
(20)\end{array}$ & $\begin{array}{c}8 \\
(8)\end{array}$ & $\begin{array}{c}1 \\
(0)\end{array}$ & $\begin{array}{c}6 \\
(-6)\end{array}$ & $\begin{array}{c}5 \\
(-10)\end{array}$ & 12 & VII \\
\hline Dividends & $\begin{array}{l}17 \\
(34)\end{array}$ & $\begin{array}{l}9 \\
(9)\end{array}$ & $\begin{array}{c}0 \\
(0)\end{array}$ & $\begin{array}{c}2 \\
(-2)\end{array}$ & $\begin{array}{c}2 \\
(-4)\end{array}$ & 37 & II \\
\hline $\begin{array}{l}\text { Capital ap- } \\
\text { preciation }\end{array}$ & $\begin{array}{l}12 \\
(24)\end{array}$ & $\begin{array}{c}12 \\
(12)\end{array}$ & $\begin{array}{c}0 \\
(0)\end{array}$ & $\begin{array}{c}5 \\
(-5)\end{array}$ & $\begin{array}{c}1 \\
(-2)\end{array}$ & 29 & IV \\
\hline Safety & $\begin{array}{c}7 \\
(14)\end{array}$ & $\begin{array}{c}9 \\
(9)\end{array}$ & $\begin{array}{c}0 \\
(0)\end{array}$ & $\begin{array}{c}5 \\
(-5)\end{array}$ & $\begin{array}{c}9 \\
(-18)\end{array}$ & 0 & VIII \\
\hline Liquidity & $\begin{array}{c}11 \\
(22)\end{array}$ & $\begin{array}{c}10 \\
(10)\end{array}$ & $\begin{array}{c}0 \\
(0)\end{array}$ & $\begin{array}{c}0 \\
(0)\end{array}$ & $\begin{array}{c}9 \\
(-18)\end{array}$ & 14 & VI \\
\hline Tax benefits & $\begin{array}{l}10 \\
(20)\end{array}$ & $\begin{array}{c}10 \\
(10)\end{array}$ & $\begin{array}{c}0 \\
(0)\end{array}$ & $\begin{array}{c}4 \\
(-4)\end{array}$ & $\begin{array}{c}6 \\
(-12)\end{array}$ & 14 & VI \\
\hline $\begin{array}{l}\text { Long-term } \\
\text { growth }\end{array}$ & $\begin{array}{c}9 \\
(18)\end{array}$ & $\begin{array}{c}16 \\
(16)\end{array}$ & $\begin{array}{c}0 \\
(0)\end{array}$ & $\begin{array}{c}0 \\
(0)\end{array}$ & $\begin{array}{c}5 \\
(-10)\end{array}$ & 24 & V \\
\hline $\begin{array}{l}\text { Short-term } \\
\text { growth }\end{array}$ & $\begin{array}{c}16 \\
(32)\end{array}$ & $\begin{array}{c}10 \\
(10)\end{array}$ & $\begin{array}{c}0 \\
(0)\end{array}$ & $\begin{array}{c}0 \\
(0)\end{array}$ & $\begin{array}{c}4 \\
(-8)\end{array}$ & 34 & III \\
\hline $\begin{array}{l}\text { Growth and } \\
\text { income }\end{array}$ & $\begin{array}{c}15 \\
(30)\end{array}$ & $\begin{array}{c}14 \\
(14)\end{array}$ & $\begin{array}{c}0 \\
(0)\end{array}$ & $\begin{array}{c}0 \\
(0)\end{array}$ & $\begin{array}{c}1 \\
(-2)\end{array}$ & $42^{* *}$ & I \\
\hline Mean & 11.9 & 10.9 & 0.1 & 2.4 & 4.7 & & \\
\hline SD & 3.4 & 2.6 & 0.3 & 2.6 & 3.0 & & \\
\hline \multicolumn{8}{|c|}{ Female (Weightage) } \\
\hline $\begin{array}{l}\text { Interest } \\
\text { rates }\end{array}$ & $\begin{array}{c}15 \\
(30)\end{array}$ & $\begin{array}{c}14 \\
(14)\end{array}$ & $\begin{array}{c}0 \\
(0)\end{array}$ & $\begin{array}{c}0 \\
(0)\end{array}$ & $\begin{array}{c}1 \\
(-2)\end{array}$ & 44 & III \\
\hline Dividends & $\begin{array}{c}6 \\
(12)\end{array}$ & $\begin{array}{l}5 \\
(5)\end{array}$ & $\begin{array}{c}2 \\
(0)\end{array}$ & $\begin{array}{c}7 \\
(-7)\end{array}$ & $\begin{array}{c}10 \\
(-20)\end{array}$ & -10 & IX \\
\hline $\begin{array}{l}\text { Capital ap- } \\
\text { preciation }\end{array}$ & $\begin{array}{c}12 \\
(24)\end{array}$ & $\begin{array}{c}7 \\
(7)\end{array}$ & $\begin{array}{c}3 \\
(0)\end{array}$ & $\begin{array}{c}3 \\
(-3)\end{array}$ & $\begin{array}{c}5 \\
(-10)\end{array}$ & 18 & V \\
\hline
\end{tabular}




\begin{tabular}{|c|c|c|c|c|c|c|c|}
\hline Influenced by & 1 & 2 & 3 & 4 & 5 & TWS $^{*}$ & Rank \\
\hline \multicolumn{8}{|c|}{ Female (Weightage) } \\
\hline Safety & $\begin{array}{c}18 \\
(36)\end{array}$ & $\begin{array}{c}11 \\
(11)\end{array}$ & $\begin{array}{c}0 \\
(0)\end{array}$ & $\begin{array}{c}0 \\
(0)\end{array}$ & $\begin{array}{c}0 \\
\text { (0) }\end{array}$ & 47 & II \\
\hline Liquidity & $\begin{array}{c}11 \\
(22)\end{array}$ & $\begin{array}{c}9 \\
(9)\end{array}$ & $\begin{array}{c}2 \\
(0)\end{array}$ & $\begin{array}{c}6 \\
(-6)\end{array}$ & $\begin{array}{c}2 \\
(-4)\end{array}$ & 21 & IV \\
\hline Tax benefits & $\begin{array}{c}9 \\
(18)\end{array}$ & $\begin{array}{c}10 \\
(10)\end{array}$ & $\begin{array}{c}1 \\
(0)\end{array}$ & $\begin{array}{c}4 \\
(-4)\end{array}$ & $\begin{array}{c}6 \\
(-12)\end{array}$ & 12 & VI \\
\hline $\begin{array}{l}\text { Long-term } \\
\text { Growth }\end{array}$ & $\begin{array}{c}22 \\
(44)\end{array}$ & $\begin{array}{c}6 \\
(6)\end{array}$ & $\begin{array}{c}0 \\
(0)\end{array}$ & $\begin{array}{c}0 \\
(0)\end{array}$ & $\begin{array}{c}1 \\
(-2)\end{array}$ & $48^{* *}$ & I \\
\hline $\begin{array}{l}\text { Short-term } \\
\text { Growth }\end{array}$ & $\begin{array}{c}7 \\
(14)\end{array}$ & $\begin{array}{c}6 \\
(6)\end{array}$ & $\begin{array}{c}3 \\
(0)\end{array}$ & $\begin{array}{c}6 \\
(-6)\end{array}$ & $\begin{array}{c}8 \\
(-16)\end{array}$ & -2 & VIII \\
\hline $\begin{array}{l}\text { Growth and } \\
\text { income }\end{array}$ & $\begin{array}{c}8 \\
(16)\end{array}$ & $\begin{array}{c}8 \\
(8)\end{array}$ & $\begin{array}{c}1 \\
(0)\end{array}$ & $\begin{array}{c}5 \\
(-5)\end{array}$ & $\begin{array}{c}8 \\
(-16)\end{array}$ & 3 & VII \\
\hline Mean & 12.0 & 8.4 & 1.3 & 3.4 & 4.6 & & \\
\hline SD & 5.4 & 2.9 & 1.2 & 2.8 & 3.7 & & \\
\hline
\end{tabular}

1: Highly Satisfied(2); 2: Satisfied (1); 3: Dissatisfied (0); 4: Highly dissatisfied (-1); 5: Neutral (-2); Source: Primary probe, 2017; *Total Weightage Score; ** $(15 \times 2+14 \times 1+0 \times 0+0 \times-$ $1+1 \times-2=42) ; * *(22 \times 2+6 \times 1+0 \times 0+0 \times-1+1 \times-2=48)$

\section{Conclusion}

The awareness level of the investors about the various investment avenues available study observed that males were largely inclined for high risk investment avenues, whereas females were more attracted towards the traditional investment avenues. The comparative analysis found that the male respondents were more interested towards realestate and the female respondents were active towards bank fixed deposits. Male investors preferred growth and income component, whereas female investors were inclined for longterm growth component and safety aspect of investment.

\section{References}

Adams, J., 2007. Research methods for graduate business and social science students. SAGE Publications, New Delhi, 270-274.

Arti, 2011. Differences in gender attitude in investment decision making in India. Journal of Finance and Accounting 2(12), 01-06.

Brahmabhatt, 2012. A study of investor behaviour on investment avenues in Mumbai. TRANS Asian Research Journals 1(1), 49-71.

Bansal, A., Kashyap, N., Mehta, P., Kumar, R.K., 2018. A study on problems and prospects of online stock trading in Solan Town of Himachal Pradesh. International Journal of Economic Plants 5(4), 184-191.

Chauhan, A., Mehta, P., Kumar, R.K., 2017. Farmers' Appraisal of the Selected Financial Schemes for Rural Development by National Bank for Agriculture and Rural Development (NABARD), Shimla District, Himachal Pradesh. India.
International Journal of Economic Plants 4(4), 141-147. Chaudhary, R., Yasmin, J., Mehta, P., Sharma, N., Kumar K., 2018. Factors Limiting rural Youth Participation in agriculture based Livelihood activities in Tehsil Karsog of Himachal Pradesh, India. International Journal of Agriculture Science and Research 8(3), 141-146.

Devi, S., 2015. Investment preference of individual. International Research Journal of Commerce and Law 2(5), 19-26.

Donald, E.F., Ronald, J.J., 1995. Security analysis and portfolio management. Pearson Publications, India, 704-706.

Gnani, Dharmaja, V., 2012. A Study on the individual investor behaviour with special reference to geojit BNP paribas financial services Ltd. International Journal of Research in Management \& Technology 2(2), 243-252.

Kapoor, K., 2016. An empirical research on the investment behaviour of rural and urban investors towards various investment avenues: A case study of Moradabad region. TMIMT International Journal 2(2), 151-156.

Kumar, K., Dutt, N., Kathuria, K., Mehta, P., Chaudhary, R., Yasmin, J., Bahir, M., 2018. Agriculture production systems, farm characteristics and managerial interventions for improved resource use efficiency in dry temperate Lahaul valley of Himachal Pradesh-India. Journal of Pharmacognosy and Phytochemistry 7(6), 1032-1036.

Khosla, P.K., Kumar, K., Dutt, N., Kathuria, K., Mehta, P., Majid F., 2018. ITKs for Land use and water management in cold deserts of Ladakh valley in Jammu \& Kashmir. Journal of Pharmacognosy and Phytochemistry 7(6), 521-524.

Kumar, K., Bahir, M., Yasmin, J., Chaudhary, R., Mehta, P., 2018. Farm characteristics, microfinance and its use in diversified agriculture by the farming communities of Kandaghat block in Solan district of Himachal Pradesh. India. Journal of Pharmacognosy and Phytochemistry 7(5), 1788-1790.

Kumari, M., Mehta, P., Kumar, R.K., 2016. Farmers' perceptions towards marketing problems and challenges in floriculture in Solan District of Himachal Pradesh, India. International Journal of Economic Plants 3(4), 143-149.

Murithi, S., Suriya, 2012. Investor's behaviour in various investment avenues-a study. International Journal of Marketing and Technology 2(7), 164-189.

Mehta, P., Thakur, A.K., Chauhan, I., Uprety, N., 2018. A Study on the Influence of Hindu Mythological characters on Management Practices. International Journal of Economic Plants 5(3), 116-122.

Mehta, P., Negi, A., Chaudhary, R., Yasmin, J., Thakur, P., 2018. A study on managing crop damage by wild animals in Himachal Pradesh. International Journal of Agriculture Sciences. Bioinfo Publications, New Delhi, India 10(12), 6438-6442.

Mehta, P., 2013. Market Orientation- A key to innovations in marketing of agro based products. International Journal of Farm Sciences. Volume 3(2), 108-112. 
Mehta, P., 2013. Production and Marketing of Apple fruit crop- a study premise to Shimla district of Himachal Pradesh-India. International Journal of Bio-resource and Stress Management 4(4), 609-612.

Mehta, P., 2011. Mentoring \& Coaching- A case of Himachal Pradesh, India. International journal of multidisciplinary management studies 1(3), 56-64.

Mehta, P., 2011. Users Perception of E-Learning Facilities at Agricultural University Library. Indian Journal of Agricultural Library and Information Services 27(2), 123-127.

Mehta, P., Sharma, M., 2014. Organizational conflict and its resolution strategies. International Journal of Advanced Research in Management and Social Sciences, Greenfield Advanced Research Publishing House 3(9), 169-176.

Odean, 1998. Are investors reluctant to realize their losses? The Journal of Finance 3(5), 13-14.

Parimalakanthi, K., Kumar, M., Ashok, 2015. A study on investment preference and behaviour of individual investors in Coimbatore city. International Journal of Industrial Engineering and Management Science3(6), 170-174.

Patil, S., Nandawar, K., 2014. A study on preferred investment avenues among salaried people with reference to Pune, India. Journal of Economics and Finance 5(2), 09-17.

Prajapati, K., Barad, K., 2013. To study the investors' behaviour towards life insurance products. International Journal for Research in Management and Pharmacy 2(1), 24-32.

Raheja, S., Lamba, B., 2013. Behaviour of investors towards investment. Indian Journal of Applied Research3(10), 01-02.

Ravichandran, K., 2008. A study on investors' preference towards various investment avenues in capital market with special reference to derivatives. Journal of Contemporary research in Management 3(3), 101-112.

Rashmi, C., Yasmin, J., Mehta, P., Verma, T., 2016. An analytical study of apple marketing channels in Himachal Pradesh, India. International Journal of Bio-Resource and Stress Management 7(2), 291-294.

Sharma, M., Thakur, R., Mehta, P., 2014. Economic stability analysis of major flower crops in Himachal Pradesh state of India. International Journal of Advanced Research in Management and Social Sciences, Greenfield Advanced Research Publishing House 3(9), 24-40.

Selvi, Tamil, T., 2015. Investor's attitude towards investment avenues. International Journal of Management and Commerce Innovations 3(1), 717-722.

Shukla, Neha, S., 2016. Investors' preference towards investment avenues with special reference to salaried personnel in north Gujarat region. International Journal for Science and advance Research in Technology2(1), 43-49.

Sireesha, P., Bhanu, Laxmi, C.H., Sree, 2013. Impact of demographics on select investment avenues: A case study of twin cities of Hyderabad and Secunderabad, India. International Journal of Marketing, Financial Services and Management Research 2(6), 47-55.

Thakur, P., Piyush, M., Gupta, N., 2017. An impact study of food product packaging on consumer buying behaviour: a study premise to Himachal Pradesh-India. International Journal of Bio-resource and Stress Management 8(6), 882-886.

Vasagadekar, P., 2014. A research paper on investment awareness among Indian working women with reference to Pune region. International Journal of Scientific and Engineering Research 5(6), 1334-1350.

Yasmin, J., Chaudhary, R., Mehta, P., Sharma, N., Kumar, K., 2018. A study on students' Perceptions on Online Shopping and factors influencing online buying behaviour. Journal of Emerging Technologies and Innovative Research 5(8), 881-886. 